\title{
Simulating crop-water production functions using crop growth models to support water policy assessments
}

DOI:

10.1016/j.ecolecon.2018.05.019

\section{Document Version}

Accepted author manuscript

Link to publication record in Manchester Research Explorer

\section{Citation for published version (APA):}

Foster, T., \& Brozovic, N. (2018). Simulating crop-water production functions using crop growth models to support water policy assessments. Ecological Economics, 152, 9-21. https://doi.org/10.1016/j.ecolecon.2018.05.019

\section{Published in:}

Ecological Economics

\section{Citing this paper}

Please note that where the full-text provided on Manchester Research Explorer is the Author Accepted Manuscript or Proof version this may differ from the final Published version. If citing, it is advised that you check and use the publisher's definitive version.

\section{General rights}

Copyright and moral rights for the publications made accessible in the Research Explorer are retained by the authors and/or other copyright owners and it is a condition of accessing publications that users recognise and abide by the legal requirements associated with these rights.

\section{Takedown policy}

If you believe that this document breaches copyright please refer to the University of Manchester's Takedown Procedures [http://man.ac.uk/04Y6Bo] or contact uml.scholarlycommunications@manchester.ac.uk providing relevant details, so we can investigate your claim.

\section{OPEN ACCESS}




\title{
Simulating crop-water production functions using crop growth models to support water policy assessments
}

\author{
T. Foster ${ }^{\mathrm{a}, *}$, N. Brozović ${ }^{\mathrm{b}}$ \\ ${ }^{a}$ School of Mechanical, Aerospace $\mathcal{G}$ Civil Engineering, University of Manchester, \\ Manchester, United Kingdom \\ ${ }^{b}$ Robert B. Daugherty Water for Food Global Institute, University of Nebraska, Lincoln, \\ Nebraska, United States
}

\begin{abstract}
Crop-water production functions are important tools for quantifying effects of water scarcity and climate change on agricultural production, and are also widely used within hydro-economic models to support design of inter-sectoral water management policies. Here, we introduce a new methodology for simulating crop-water production functions using process-based crop growth models, which captures explicitly the interacting effects of farmers' intraseasonal irrigation decision-making, stochastic weather conditions, and physical and socioeconomic water supply constraints on seasonal crop yield response to water. Through a case study application for groundwater irrigated corn production in the Texas High Plains, we demonstrate that constraints to irrigation scheduling caused by aquifer depletion, combined with farmers' limited foresight of future weather conditions, have significant impacts on estimated seasonal crop-water production functions. Our results highlight that the failure to account for these factors fully in previous simulation approaches will lead to errors in estimates of the impacts of groundwater depletion on farmers' future resilience to drought and climate change. Our proposed simulation methodology is generalizable to different production systems or crop growth models, and provides a tool for assessing how economic benefits derived from irrigation vary spatially and temporally due to heterogeneity in biophysical conditions and irrigation practices.
\end{abstract}

Keywords: Crop-water production function, Hydro-economic, Irrigation, Valuation, Deficit irrigation, Climate variability

\section{Introduction}

Irrigation is fundamental to agricultural productivity and food security worldwide (FAO, 2011). However, the availability of water for agriculture is under

\footnotetext{
* Corresponding author

Email address: timothy.foster@manchester.ac.uk (T. Foster)
} 
threat in many regions due to growing competition from cities and the envi5 ronment for a share of limited freshwater resources, coupled with shifts in precipitation patterns and rising irrigation demands as a result of climate change (Elliott et al., 2014, McLaughlin and Kinzelbach, 2015).

Efforts to manage competing demands for scarce water resources from agriculture and other sectors fundamentally require knowledge of the value of irriga-

10 tion water in crop production, and how this value varies over space and time due to differences in physical (e.g. weather/climate, soil type) and socio-economic (e.g. input/output prices, regulatory context) production conditions. Central to any such economic analysis of the value of irrigation water are crop-water production functions, which describe mathematically how crop yields respond 15 to variable irrigation water inputs for a given set of climate conditions and farm management practices (Steduto et al., 2012). Crop-water production functions can be linked with farm economic models to evaluate how agricultural production and welfare outcomes will be affected by future shifts in water availability due to climate or policy change (Maneta et al., 2009; Foster et al., 2014, Esteve et al., 2015: Giuliani et al., 2016). Moreover, production functions also provide an essential input to hydro-economic modelling studies that seek to quantify the economic impacts of basin-scale policies to determine the optimal allocation of water use between agriculture and other users such as the environment, cities or hydropower (Cai et al., 2003, Bekchanov et al., 2015, Erfani

25 et al., 2015; Kahil et al., 2015). For example, production functions linked with basin-scale hydro-economic models can provide a powerful tool for evaluating spatial and temporal trade-offs between agricultural profitability and environmental outcomes in groundwater-fed irrigation systems, where impacts of spatially distributed pumping on hydrologically-connected surface water ecosystems are a major driver of policy efforts to regulate agricultural water abstractions (Kuwayama and Brozović, 2013). Accurate estimation of crop-water production functions therefore is essential for accurate prediction of the impacts of water scarcity on agriculture, and for reliable design of economically efficient policies to manage rising inter-sectoral competition over limited freshwater resources 5 globally.

Historically, crop-water production functions have been developed based on empirical observations of crop yield response to applied irrigation from surveys of farms or regions (Hexem and Heady, 1978, Barrett and Skogerboe, 1980 , Ayer and Hoyt, 1981; Moore and Negri, 1992, Zhang and Oweis, 1999, Kipkorir

40 et al. 2002). However, due to the large costs associated with collecting empirical datasets and challenges in generalizing empirical functions to new environments or changing hydrological conditions (Young and Loomis, 2014), it is increasingly common for mathematical crop models to be used to simulate crop-water production functions for use in economic water policy analysis. Such models enable

45 rapid assessment of the value of irrigation across diverse production conditions that would be infeasible using empirical techniques, and have been widely used as part of hydro-economic studies to support basin-scale water policy design and inter-sectoral water resource allocation (e.g. Kuwayama and Brozović (2013); Kahil et al. (2015); Esteve et al. (2015); Giuliani et al. (2016); Noël and Cai 
When applying simulation models to estimate crop-water production functions, a major challenge is the mismatch between the temporal resolution of production functions used in hydro-economic research and water policy, which are either seasonal or annual, and that of crop growth models, which typically run

55 on a daily time step. Commonly, an assumption is made that limited seasonal irrigation will be scheduled optimally within each growing season, for example by linking the simulation model with optimization algorithms to determine the sequence of irrigation decisions (timing and rates) that maximize crop yields for different levels of total seasonal irrigation (Brumbelow and Georgakakos, 60 2007, Schütze and Schmitz, 2010; Linker et al., 2016). However, this approach introduces several unrealistic assumptions about farmers' intraseasonal irrigation decision-making, specifically that the farmer has perfect foresight of future weather and irrigation demands, and that no constraints exist to when and how irrigation can be applied during the growing season. In reality, producers make irrigation decisions based on limited information about future weather conditions due to the imperfect nature of weather forecasts (Jones et al. 2000 , Shafiee-Jood et al., 2014), and irrigation scheduling is affected by a range of physical, technical, social, and regulatory constraints to water availability (Foster et al. 2014; Smilovic et al., 2016). Correct characterization of the rules

70 and constraints that underlie intraseasonal irrigation decision-making is critical for reliable estimation of seasonal crop-water production functions, and, thus, for the reliability of water policy and management assessments that are based on these functions. Yet, to date, the majority of studies that have used crop growth models to simulate crop-water production functions have not considered 75 explicitly limits to farmers' foresight about future climate and intraseasonal irrigation scheduling, thus potentially reducing the accuracy of resultant estimates of seasonal crop-water production functions and water policy assessments based on these functions.

In this paper, we make two main contributions to the literature on developso ment of crop-water production functions for economic analysis of agricultural water use and management. First, we provide a detailed review of the different approaches used to estimate crop-water production functions, focusing, in particular, on recent applications of crop simulation models since previous reviews published on this topic (Vaux and Pruitt, 1983, Dinar and Letey, 1996.

${ }_{85}$ McKinney et al. 1999). Second, we introduce a novel methodology for applying crop simulation models to develop seasonal crop-water production functions for use in hydro-economic studies of agricultural water management. Our approach provides a framework for simulating crop-water production functions in agricultural systems where farmers' irrigation decisions are influenced strongly

90 by stochastic and uncertain weather conditions during the crop growth season, and where intraseasonal irrigation scheduling decisions are constrained significantly by physical, economic, or technical factors. We demonstrate the utility of our simulation approach through an illustrative application for irrigated corn production in the Texas High Plains, an area where producers increasingly face 95 significant constraints to irrigation decision-making due to regulatory changes 


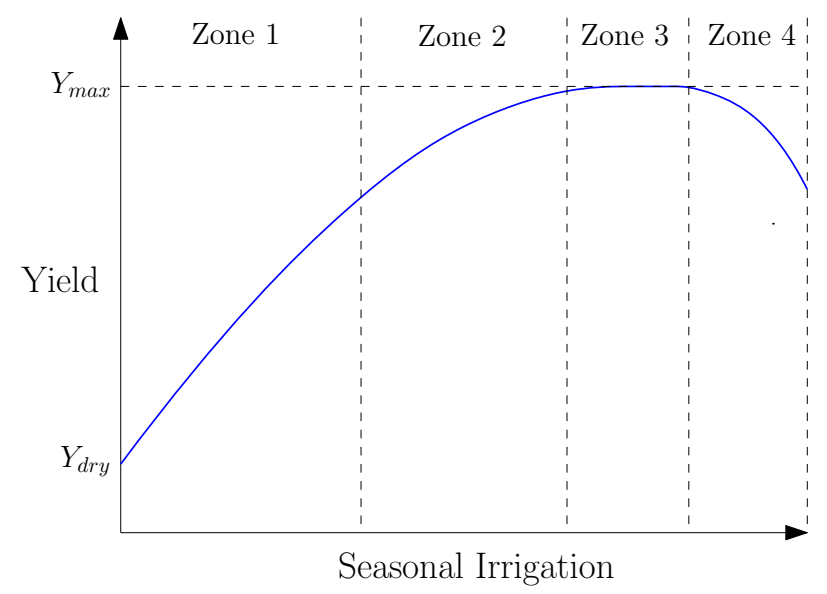

Figure 1: Typical relationship between total seasonal irrigation and crop yield. Four main stages or zones of the production function are noted where marginal crop yield returns to irrigation are: (1) approximately linear, (2) less than linear/diminishing, (3) zero, and (4) decreasing

to water policy and depletion of groundwater storage. Our results illustrate that timing of irrigation, expectations of climate, and intraseasonal irrigation supply constraints all have large impacts on estimated seasonal crop-water production functions. Critically, failure to consider these factors is likely to lead to misleading estimates of the impacts of drought and rising water scarcity on farmers' and rural economies, highlighting the value our proposed simulation approach to support improved economic analysis of agricultural water use and management globally.

\section{Crop-water production functions: A review}

The crop-water production function expresses the relationship between seasonal applied irrigation and crop yield. Some agronomic studies have proposed an alternative definition of the production function, in which seasonal evapotranspiration rather than applied irrigation is specified as the dependent variable (Doorenbos and Kassam, 1979, Igbadun et al., 2007; Geerts and Raes, 2009).

110 However, for the purposes of economic analysis of agricultural water use and management, it is common to adopt the former definition of the crop-water production function, as applied irrigation water is the variable that is of greatest significance to policymakers, water managers, and farmers.

Figure 1 illustrates the typical relationship between seasonal applied irrigation and crop yield. It is noticeable that the crop-water production function is concave and can be divided approximately in to four sections. In Zone 1, almost all applied water is consumed by the crop and converted in to harvestable yield, and hence the crop-water production function has an approximately linear slope. However, as the level of applied water is increased (Zone 2), marginal 
returns to further irrigation diminish as increasing proportions of applied water are lost through non-beneficial (i.e. non-consumptive) processes such as soil evaporation, deep percolation, and surface runoff. Eventually, yield reaches a theoretical maximum (Zone 3) beyond which further application of irrigation will not increase yield (as the crop is transpiring at maximum rate) and, in some cases (Zone 4), may even decrease yields due to water logging of the root zone and creation of anaerobic conditions that limit transpiration.

The shape of the crop-water production function in Figure 1 has important implications for the economics of irrigation decision-making and agricultural water management (English, 1990; English et al., 2002). Given the concave shape of the crop-water production function, for non-zero water prices, the profitmaximizing and yield-maximizing rates of irrigation water use will be different. Specifically, as water prices increase it will be optimal economically for farmers to irrigate at rates below full crop water requirements to maximize the economic productivity of irrigation water use - a strategy known as 'deficit irrigation'. It is important to highlight, however, that the idealized concave shape of the cropwater production function in Figure 1 may not always be valid. For example, in drought years a minimum level of irrigation may be required to avoid crop failure and produce any harvestable yield (Shani et al., 2004, Foster et al., 2015). Similarly, the curvilinear shape may also be altered if limited seasonal irrigation 140 water is scheduled sub-optimally during the growing as a result of water availability or information constraints (Foster et al. 2014 Smilovic et al. 2016). In these situations, the economic benefits of deficit irrigation strategies may be reduced due to the greater yield reductions that would be incurred by the farmer. These issues will be discussed further in subsequent sections, with particular emphasis placed on the ability of alternative estimation or simulation methods to capture changes in the functional form of the crop-water production function caused by each of these factors.

\subsection{Empirical estimation approaches}

Empirical approaches for estimating crop-water production functions use statistical methods to fit functional relationships to observation data describing crop yield response to varying levels of irrigation water inputs. Observation data used to generate these empirical relationships most commonly are obtained from field experiments or farm surveys. Experiments typically are conducted over multiple years to capture variability in the crop-water production function caused by inter-annual differences in weather conditions during the growing season (principally rainfall, but also temperature as this influences crop water requirements and growing season length). In some cases, levels of other inputs (e.g. fertilizers) may also be varied to produce multi-input production functions. However, for the purposes of this paper, we focus primarily on the development of crop-water production functions holding the level of other inputs constant.

Numerous examples exist in the literature describing the use of empirical methods to develop crop-water production functions. One of the most widely cited is the study by Hexem and Heady (1978), who used data from field experiments across a range of sites and climatic years to develop crop-water produc- 
tion relationships for corn, wheat, cotton, and sugar beets in the western United States (the authors also considered confounding effects of variable nitrogen levels). Similar studies have also been conducted by other authors for a range of crop types and production systems worldwide (e.g. Barrett and Skogerboe (1980); Ayer and Hoyt (1981); Dinar et al. (1986); Zhang and Oweis (1999);

170 Kipkorir et al. (2002); Igbadun et al. (2012)). These studies commonly report a curvilinear relationship between seasonal irrigation and crop yield, similar to that shown in Figure 1, but also highlight that there is typically wide variability in the relationship between applied water and crop yield across sites and years due to differences in management practices and climatic conditions.

175 Well designed field experiments or surveys have the potential to generate highly reliable estimates of crop yield response to irrigation water inputs. However, empirical approaches also suffer from a number of critical limitations that have restricted use in hydro-economic research and water policy assessments to date. Most significantly, collecting sufficient data to capture variability in cropwater production functions for different crop types and production conditions is extremely time consuming and costly (McKinney et al., 1999; Young and Loomis, 2014). This limitation is particularly apparent when considering the effects of intraseasonal irrigation scheduling on crop growth and yields, which may require large numbers of experiments to be performed to capture the vari-

185 ability in yield response to seasonal irrigation caused by differences in the timing of, and/or constraints to, irrigation within the growing season. Some studies propose the use of cross-sectional observation data as a way of estimating empirical production functions at lower cost (e.g. Moore and Negri (1992)). However, such approaches are rare in the literature due to the almost universal lack of 90 accessible field-level water use and crop yields in both developed and developing countries. Moreover, while crop-water production functions estimated using empirical datasets may implicitly capture constraints to water use decisions including technology and delivery systems limitations, such functions cannot be readily extrapolated to other systems where constraints may differ. In partic-

195 ular, estimated production functions will be unable to capture adequately the impacts of policy or hydrologic change on constraints to farmers' water use decisions, which are a major driver of production risk and farm profitability in many regions worldwide.

\subsection{Mathematical modeling approaches}

200 As an alternative to empirical estimation of crop-water production functions, mathematical models instead can be used to simulate synthetic data describing crop yield response to water inputs across a relevant range of production conditions and management practices. Similarly to empirical estimation approaches, crop-water production functions are then determined by fitting mathematical functions to synthetic simulated crop yield and water use data. In general, mathematical models used to simulate crop-water production functions fall in to two main categories: (1) crop coefficient models and (2) process-based crop growth models, each of which are discussed in turn below. 


\subsubsection{Crop coefficient models}

An extensive literature has demonstrated the fundamental biophysical relationship between crop yield and evapotranspiration (Stewart and Hagan, 1973. Hanks, 1974; Steduto et al. 2007). The basic functional relationship between evapotranspiration and crop yield is given by Equation 1, which expresses relative crop yield (i.e. the ratio of actual to potential crop yield, $Y_{a} / Y_{p}$ ) as a function of the relative seasonal crop evapotranspiration rate $\left(E T_{a} / E T_{p}\right)$ and a crop yield response factor $\left(K_{y}\right)$ that defines crop sensitivity to water deficits (Doorenbos and Kassam, 1979).

$$
1-\frac{Y_{a}}{Y_{p}}=K_{y}\left(1-\frac{E T_{a}}{E T_{p}}\right)
$$

Crop coefficient models combine Equation 1 with soil water balance methods to estimate the relationship between seasonal irrigation water use and crop yields. A major advantage of such models is their relative simplicity and low data requirements, enabling rapid estimates of crop yield response to water to be generated based on fundamental crop water use principles. However, a shortcoming of crop coefficient models based on Equation 1 is that water deficits are assumed to have identical impacts on crop yield irrespective of the timing of deficits during the growing season. In reality, crop sensitivity to water deficits varies according to the stage of crop development (Doorenbos and Kassam, 1979 . Steduto et al. 2012), and final yield will depend on the specific intertemporal sequence of water deficits during the growing season. To account for these effects, a range of more complex crop coefficient models have been developed where the

230 response coefficient, $K_{y}$, is varied by growth stage. Crop yield resulting from a sequence of irrigation decisions and water deficits is then estimated using one of two main approaches. Additive models (e.g. Stewart et al. (1977); Bras and Cordova (1981)) assume that effects of water deficits in each growth stage can be summed together to determine final crop yield. Alternatively, multiplicative models (e.g. Jensen (1968); Minhas et al. (1974)) specify that evapotranspiration deficits in two or more growth stages affect final yield in a multiplicative manner. There is no accepted consensus in the literature about which formulation produces the most reliable estimates of yield response to water (Igbadun et al. 2007), although some authors have argued that multiplicative models capture more robustly the interacting effects of water deficits across multiple growth stages (Rao et al., 1988, Raes et al., 2006), in particular where water deficit in specific growth stages can cause disproportionately large damage to crop yields (e.g. due to failure of crop pollination for grain crops).

Crop coefficient models have been widely used to simulate crop yield responses to variable irrigation water inputs (Scheierling et al., 1997; Shani et al. 2004 Smilovic et al., 2016), and have also been applied extensively as part of broader hydro-economic (Sunantara and Ramírez, 1997, Cai, 2008, Esteve et al., 2015, Giuliani et al., 2016; Noël and Cai, 2017) and water resource planning models (e.g WEAP - (Yates et al., 2005)) used to support agricultural water 
theory of crop-water relations, the ability of such models to generate reliable estimates of complex crop yield responses to water is limited by a number of factors. Specifically, the empirical nature of crop coefficient models makes it challenging to determine which model formulation should be used (e.g. additive or multiplicative), and to define accurate values for yield response parameters. Previous studies have demonstrated large variability in values of $K_{y}$ between and within crop types, which cannot be explained reliably by differences in environmental conditions or management practices (Kaboosi and Kaveh, 2012 Steduto et al. 2012). Furthermore, due to the inherent linearity of Equation and related models, evapotranspiration modeling approaches perform poorly under extreme water stress conditions where the response of crop growth to water deficits typically is highly non-linear (Steduto et al., 2009, Brown et al., 2010). Errors may also be further compounded if water stress varies significantly within individual growth stages, leading to an underestimation of yield reductions when using crop coefficient models that aggregate impacts of water deficits within development periods (Raes et al., 2006). Finally, use of crop coefficient models is dependent on knowledge of the maximum or potential crop yield, and, as a result, the accuracy of such models will be reduced in areas where reliable data on non-limited crop yields is unavailable (e.g. in developing world settings).

\subsubsection{Crop growth models}

Motivated by the limitations of crop coefficient models and the growth in computing power in recent years, there has been increasing interest in the application of more complex process-based crop growth models for simulating crop yield response to water in hydro-economic research and economic water policy analysis (Brumbelow and Georgakakos, 2007; Geerts and Raes, 2009; Schütze and Schmitz, 2010: García-Vila et al., 2009 García-Vila and Fereres, 2012; Foster et al., 2014, 2015, Kim and Kaluarachchi, 2016). Crop growth models are mathematical models that simulate the growth, development, and yield of a crop

280 for a given set of environmental conditions (e.g. weather, soil type) and management practices (e.g. irrigation/fertilizer applications) (Monteith, 1996). A huge diversity of crop growth models are documented in the literature, for example AquaCrop (Steduto et al., 2009; Foster et al., 2017b), DSSAT (Hoogenboom et al. 2004), and APSIM (Keating et al., 2003). Notwithstanding differences in methods used to simulate crop growth, the majority of crop growth models contain detailed representations of crop physiological responses to water deficits. As a result, when adequately calibrated and validated, such models provide a powerful tool for estimating crop-water production relationships and improving the biophysical realism of irrigation water valuation and policy analysis. In

290 particular, crop growth models are able to estimate realistically the response of crop yields to specific inter-temporal sequences of irrigation decisions and water deficits at fine timescales (e.g. daily) within the growing season, which would be infeasible using either empirical estimation approaches or simpler crop coefficient models. Moreover, in comparison with empirical approaches, crop growth models can be used to estimate rapidly the variability in crop yield response to 
water across a range of potential environmental and management conditions. For example, several studies have used crop simulation models to quantify the stochastic nature of the crop-water production function resulting from interannual weather variability (e.g. Schütze and Schmitz (2010); García-Vila and Fereres (2012); Foster et al. (2014)) in order to understand how the value and productivity of water use varies over time as a function of climatic conditions both now and in future years.

While crop growth models undoubtedly have great potential to improve representation of crop-water relationships in hydro-economic research, two imporment of the value of water in agriculture and effectiveness of alternative policy options. First, crop growth models must be calibrated and validated against appropriate experimental/observation data to ensure simulated yield response to water represents reality accurately over the desired range of production conditions. In this regard, calibration should not be limited to parameter adjustment, and should also consider the intrinsic capacity of the selected model to capture key crop physiological responses to water deficits (Monteith, 1996). Second, methods for using crop growth models to simulate crop-water production functions must also capture realistically the structure, drivers, and constraints 315 underlying farmers decisions about the intraseasonal timing and rates of irrigation, which in turn may have large impacts on estimates of crop yield response to total seasonal irrigation and resultant economic predictions of agricultural water demands or abatement costs based on these functions (Scheierling et al. 1997; Shani et al., 2009, Foster et al., 2014, Smilovic et al., 2016). Crop model calibration is not the primary focus of this paper, and, therefore, the discussion below focuses on current challenges faced when attempting to represent farmer irrigation decision-making within simulated crop-water production functions.

A common challenge when seeking to simulate crop-water production functions is how to address the temporal disconnect between crop growth models, 325 which typically run on a daily time-step, and crop-water production functions used in economic policy analysis, which traditionally have described crop yields as a function of total seasonal irrigation inputs. In many cases, crop models have been linked with optimization algorithms in order to determine the optimal scheduling, or intraseasonal timing, of limited seasonal irrigation within 330 the growing season (e.g. Schütze and Schmitz (2010); García-Vila and Fereres (2012); Linker et al. (2016)). This approach introduces several assumptions about intraseasonal decision-making, specifically that farmers have perfect foresight of daily weather conditions during the upcoming season and face no limits or constraints to potential timing of irrigation events. However, in reality, many farmers face very high levels of uncertainty about weather conditions more than a few days ahead and therefore make decisions about irrigation water allocation using heuristics, which account for knowledge about crop sensitivity to water deficits and expectations of future weather. Indeed, a recent survey of around 230,000 farmers in the United States by the U.S. Department of Agriculture (U.S. Department of Agriculture, 2013) identified the main methods used to schedule irrigation as "condition of the crop" and "feel of soil". In addition, 
farmers often also face a wide range of constraints that may affect when and how they are able to irrigate their crops. For example, on any given day, a producer may be unable to irrigate due to restrictions on the timing of surface water deliveries (O'Keeffe et al., 2016) or supply of energy for pumping groundwater (Mieno, 2014), physical limits to the capacity of irrigation systems (Foster et al. 2014), or regulatory policies that restrict when and how much water may be abstracted for irrigation (Palazzo and Brozović, 2014). Previous studies have demonstrated the significant impacts of intraseasonal irrigation timing on crop s (Scheierling et al., 1997: Shani et al., 2004: Smilovic et al. 2016) due to variability in the sensitivity of crop development to water deficits at different points within the crop growing season. However, these studies typically have considered only a limited range of potential intraseasonal management practices or constraints when assessing crop yield impacts, such as arbitrary fixed irrigation events or dates, which may not be representative of farmers' true irrigation scheduling decisions in many regions. Similarly, to date, no comprehensive approach has been proposed for simulating farmers' expectations of crop-water production functions in the presence of both intraseasonal irrigation constraints and stochastic climate conditions, which are typical of the majority of irrigated 360 agricultural production systems worldwide.

\section{Methodology}

In this section, we describe the development of a new approach for simulating crop-water production functions using process-based crop growth models that accounts explicitly for farmers' limited foresight of future climate conditions,

365 along with the impacts of a range of possible physical and regulatory constraints to intraseasonal irrigation scheduling during the growing season.

\subsection{Modeling approach}

We propose a new generalizable approach to operationalize the use of processbased crop growth models for simulating crop-water production functions con-

370 ditional on realistic assumptions about the information structure and heuristics underlying farmer irrigation decision-making and crop physiological responses to irrigation water inputs. The overarching framework of this modeling approach is shown in Figure 2, and consists of a series of key steps and calculations that are discussed in turn below.

375 Crop yield and seasonal irrigation water use, the two variables that define a crop-water production function, both depend significantly on climate conditions and irrigation practices within the crop growing season. As a result, the first step of our simulation framework involves constructing a representative set of climate and irrigation management scenarios that will act as inputs to the crop growth 380 model. Climate scenarios should reflect farmers' expectations about the potential variability in growing season weather conditions, both in terms of aggregate seasonal differences and the distribution of daily weather conditions within individual seasons. Required data (time-series of daily temperature, precipitation, 


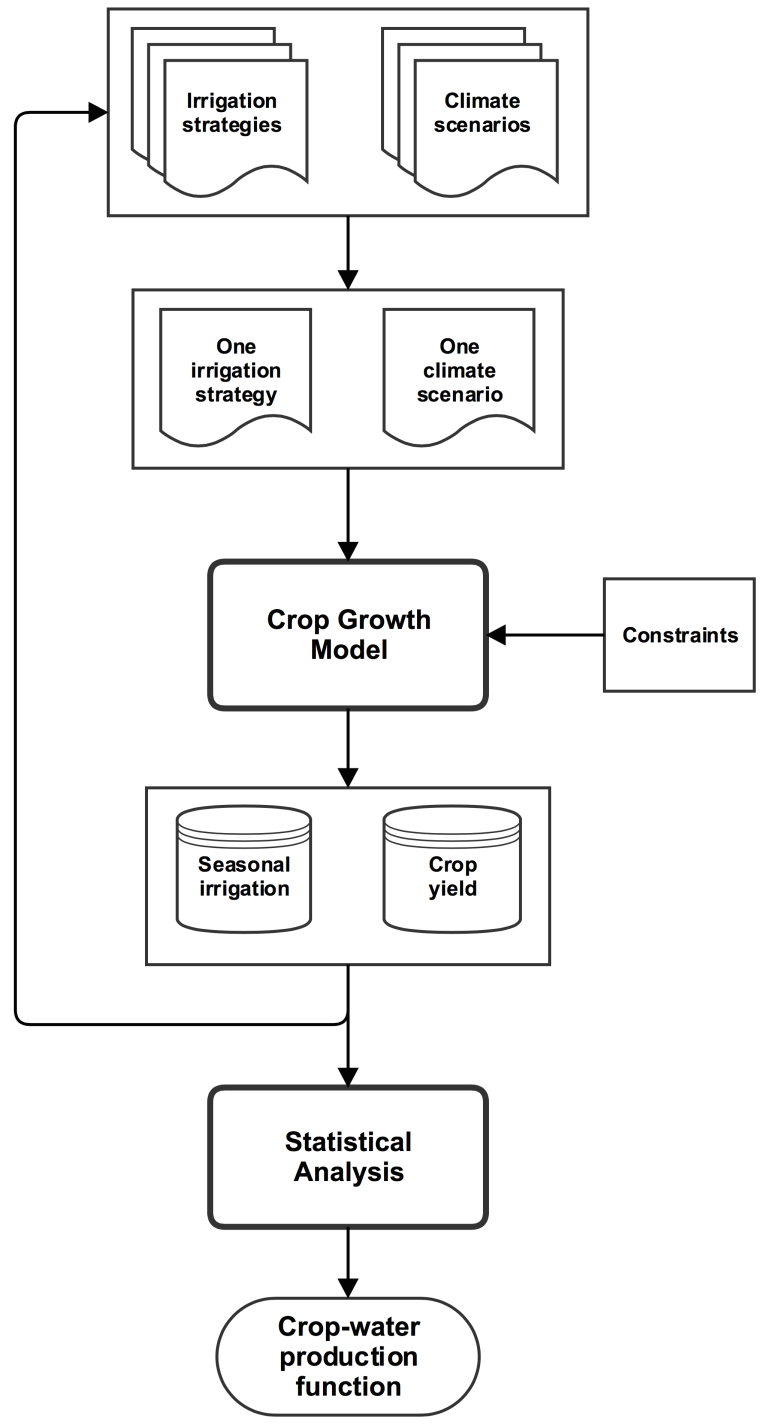

Figure 2: Flow chart showing the framework used to simulate crop-water production functions for a given set of potential intraseasonal irrigation management strategies, climate scenarios, and irrigation decision constraints 
and reference crop evapotranspiration) are obtained from historic weather oberation models (e.g. Semenov et al. (1998)). Irrigation management scenarios represent the range of possible irrigation strategies that the farmer could adopt to trigger/schedule irrigation during the growing season. The modeler must make choices about the criteria that irrigation will be triggered based on (e.g.

390 soil moisture status), and to what extent trigger points are varied throughout the simulated growing season (e.g. to reflect varying sensitivity to water stress in different growth stages). Simulations account implicitly for differences in irrigation efficiency caused by farmers' intraseasonal irrigation scheduling practices. For example, if seasonal irrigation is scheduled in a small number of large discrete events, such as would occur in a flood irrigation system, then significant proportions of applied water may be lost to deep percolation below the crop root zone thus increasing required seasonal irrigation depths to achieve a given crop yield. Similarly, as part of the simulations, the modeller may also specify additional parameters or factors within the crop model that influence the efficiency of irrigation applications, such as the proportion of the soil surface that is wetted during irrigation events which influences non-consumptive losses through soil evaporation. Critically, our proposed simulation framework therefore ensures that assumptions about farmers' intraseasonal timing of irrigation, and their effects on irrigation efficiency and final crop yields, are acknowledged This is in contrast to previous research that, with few exceptions Scheierling et al., 1997; Shani et al., 2004; Smilovic et al., 2016), has treated irrigation as a lumped seasonal total and ignored the importance of farmers' intraseasonal irrigation scheduling choices. Data required to specify irrigation management rules may be based on known information about specific farmer practices in a given production system or region, for example from surveys or in-situ monitoring. Alternatively, where such information is unavailable, management rules instead may be defined according to more generalised assumptions about the criteria for triggering irrigation events (e.g. based on soil moisture status), which re-

415 flect underlying biophysical drivers of crop water stress and typical scheduling practices associated with different irrigation technologies (e.g. flood, sprinkler, drip).

Once a representative set of climate and irrigation management scenarios have been defined, a crop growth model is then run to simulate total seasonal irrigation water use (Equation 2) and crop yield (Equation 3) for a combination of one irrigation management strategy and weather conditions for a single growing season.

$$
\begin{gathered}
I=\sum_{t=1}^{t=N} i_{t}=f(W, M, C) \\
Y=f(X, i)
\end{gathered}
$$

Where: 
I : total seasonal irrigation depth $[\mathrm{L}]$

i : daily irrigation depth $[\mathrm{L}]$

$\mathrm{Y}$ : crop yield $\left[\mathrm{M} / \mathrm{L}^{2}\right]$

$\mathrm{W}$ : time-series daily weather conditions during the growing season

$\mathrm{M}$ : irrigation management strategy

$\mathrm{C}$ : constraints to irrigation decision-making

$\mathrm{t}$ : day of growing season

$\mathrm{N}$ : total number of days in the growing season

Crop growth simulations run on a daily time-step, estimating at each step dynamic changes in soil water status and crop growth resulting from weather conditions and irrigation decisions. Simulated seasonal irrigation water use and crop yield for any joint climate and irrigation management scenario are also influenced by constraints that limit farmers' irrigation decisions during the simulated growing season. Specified constraints can be either intraseasonal or seasonal. Intraseasonal constraints could include limits on how much water can be applied, for example if the maximum daily irrigation depth is limited by 440 irrigation system capacity, and/or on when irrigation can be triggered, such as if there is a minimum interval between irrigation events or if there are time periods when irrigation is curtailed to avoid impacts on other water users and/or the environment. In contrast, seasonal constraints are based primarily on the total volume/depth of irrigation water used, for example regulatory restrictions on total abstraction over a growing season. In each case, specified constraints limit when and how much irrigation can be applied in the crop growth model, ensuring that simulated crop yield response to water captures implicitly underlying constraints to farmers' water use decision-making and impacts on expected seasonal crop-water production relationships.

The simulations described above are repeated for all possible combinations of climate conditions and irrigation management practices identified in step one of the framework. The resulting outputs are two separate 2D matrices describing crop yields and irrigation water use, respectively, for all possible climate and irrigation management scenarios, given specified constraints to irrigation decisions. Using these datasets, a crop-water production function is then extracted using a three step procedure. First, crop yields and irrigation water use are analyzed using statistical methods to calculate an expected crop yield and water use for each irrigation management strategy, reflecting the fact that the farmer does not know with certainty what weather conditions will be in any 460 given growing season when making decisions about what crops to plant, how much land to irrigate, and how seasonal irrigation should be allocated during the upcoming season. The simplest statistical approach involves averaging across climate scenarios, but, alternatively, the median or percentiles could be taken to reflect different expectations about climate (e.g. drier or wetter). Subsequently, 

(e.g. 0-50mm, 50-100mm, etc.), and for each bin the maximum expected crop yield is extracted. Implicitly, this step assumes that, given a desired level of seasonal irrigation water use, the farmer will adopt an intraseasonal irrigation strategy that maximizes crop yields, conditional on uncertainty about future 470 climate and specified constraints to irrigation decision-making. However, this step in our methodology could also be adapted easily to consider alternative assumptions about farmers' decision-making under climate uncertainty, for example if farmers' are risk averse and aim to not only maximise expected crop yields but also reduce variance in yields from year to year. Similarly, heuristics 475 used to model farmers' intraseasonal irrigation decisions could also be modified to account for systems where farmers' may have imperfect knowledge of soil water conditions and as a result use alternative rules to trigger irrigation events, for example in smallholder agricultural systems or regions where on-farm technology such as soil moisture probes have yet to be widely adopted by producers. pected irrigation water use and crop yield, using a non-parametric approach due to the possibility that the crop-water production function may diverge from the shape shown in Figure 1 when irrigation scheduling is strongly constrained (Foster et al., 2014, Smilovic et al., 2016).

485 Our proposed methodology for simulating crop-water production functions differs from previous estimation approaches in several ways. Specifically, our approach accounts explicitly for impacts on crop-water production functions of both: (i) stochastic weather conditions and associated uncertainty in farmers' expectations of crop yields and irrigation requirements, and (ii) potential reductions in crop yields resulting from constraints to intraseasonal timing and rates of irrigation during the growing season. This is in contrast to the majority of existing approaches for modeling crop-water production functions, which assume farmers' have perfect foresight of daily weather during the growing season and can freely adjust irrigation schedules to maximize crop yields (Schütze and 495 Schmitz, 2010; García-Vila et al., 2009, García-Vila and Fereres, 2012; Foster et al., 2015; Kim and Kaluarachchi, 2016). Two notable exceptions to this trend are the studies of (Scheierling et al., 1997) and (Smilovic et al., 2016), which both consider explicitly the impacts of effects of intraseasonal irrigation timing on crop yield response to seasonal water inputs. Nevertheless, these studies 500 rely on simplified crop coefficient models that do not capture fully the complex non-linear response of crop growth and yields to water stress. Moreover, both (Scheierling et al. 1997) and (Smilovic et al., 2016) assume that farmers' irrigation decisions are made under deterministic weather conditions, and thus their approaches are unable to evaluate the interacting effects of stochastic weather and intraseasonal irrigation timing on expected seasonal crop yield response to water. In contrast, the approach presented here provides a robust method for simulating crop-water production functions, which considers both the biophysical response of crop yields to climate and farmers' intraseasonal irrigation management choices. Our approach is generalizable to different crops, 510 geographic locations, and irrigation system specifications. Furthermore, the 
framework can be applied using different crop growth models, the only requirement being that the model is capable of representing key drivers and constraints underlying irrigation decision-making for the system being evaluated.

\subsection{Example application} late crop-water production functions for an example case study of irrigated corn production in Texas, United States. Corn is one of the most important irrigated crops in Texas, with production area of greater than 1 million ha and annual revenue in excess of $\$ 1$ bn (data available at: https://quickstats.nass . usda. gov/). Rainfall in region is highly variable from year to year, but almost always is insufficient to meet crop water requirements fully meaning that maize production typically is irrigated. Irrigation water is sourced predominantly from groundwater stored in the High Plains Aquifer, which underlies much of the Texas High Plains. However, high rates of abstraction in excess of natural ${ }_{525}$ recharge have depleted significantly groundwater storage over recent decades (Haacker et al. 2015$)$. As a result, many farmers have experienced large increases in pumping costs and reductions in the yields of wells used for irrigation pumping, and there is growing recognition of the need for improved management to reduce groundwater extraction and extend the usable lifetime of the aquifer (Foster et al., 2017a). Each of these factors make corn production in the Texas High Plains an ideal test case to illustrate the power of our proposed modeling framework to simulate crop-water production function that capture realistically the interacting effects of stochastic climate conditions, irrigation supply constraints, farmer water use behavior on crop yield response to water 5 and the value of irrigation water as a buffer against climate variability.

The crop growth model that will be used for this example application is AquaCrop-OS version 5.0a (Foster et al. 2017b), an open-source implementation of the FAO AquaCrop model (Steduto et al., 2009). Our decision to use AquaCrop-OS is motivated by a number of factors. First, the model has a strong emphasis on representing the effects of water deficits on crop yields and provides a mechanism for specifying a wide range of potential irrigation decisions rules and constraints. Furthermore, AquaCrop-OS is also well suited to exercises where large numbers of simulations are performed, as model runs can be parallelized to reduce greatly total simulation times (Foster et al., 2017b). Applying

${ }_{545}$ AquaCrop-OS within the framework outlined in Section [3.1, we perform several illustrative simulations to demonstrate the important innovations included in our proposed simulation framework related to representation of the effects of climate uncertainty, irrigation constraints, and water use decision-making on crop yield response to water.

Following the procedure outlined in Section 3.1, crop-water production functions first are simulated representing the expected relationship between total seasonal irrigation and crop yield, assuming no physical or regulatory constraints to irrigation decisions within all individual growing seasons. Effects of climate uncertainty on expected crop-water production relationships then are explored 

tial weather scenarios (weather data are described at the end of this section): (i) all historic years, (ii) 5 driest historic years $(1990,1998,2000,2011$, and 2012), and (iii) 5 wettest historic years (1988, 1989, 1996, 2008, and 2015). Comparison across the three extracted production functions demonstrates how future irrigation water demands and crop yields. Evaluating these differences is especially relevant when seeking to use crop-water production functions to model farmers' decisions about crop choice and land allocation, which typically must be made pre-season before actual weather conditions are observed fully as a result of forced re-planting or land abandonment). Nevertheless, it is important to recognise that the specific scenarios modelled here represent only three hypothetical specifications of farmers' expectations of weather conditions, and alternative assumptions about farmers' foresight of future weather could also Similarly, estimating actual crop yield returns in any given individual year would also require connection with additional models that consider farmers' capacity to update expectations and irrigation decisions/practices as actual weather con575 ditions are observed during the growing season (Loch et al., 2013). However, this analysis is beyond the scope of the work presented in this manuscript.

Subsequently, an additional set of simulations are performed to demonstrate the ability of our proposed framework to capture effects of intraseasonal irrigation constraints on seasonal crop yield response to water. As previously noted, reductions in well yields represent a growing constraint to farmer irrigation decision-making in the Texas High Plains and other major groundwater-fed irrigation systems worldwide. Constraints imposed by well yields can be defined as either a limit on: (i) the maximum daily irrigation application depth, or (ii) the minimum number of days between irrigation events. In the former case it 585 is assumed that the irrigation system will pass over the full irrigated field area in a single day, whereas the latter scenario assumes that water is applied at a fixed rate and well yield instead limits the time taken for the irrigation system to return to a given point in the field. Using the framework described in Section 3.1. we simulate crop-water production functions for a range of possible daily ir${ }_{590}$ rigation constraints ( $1 \mathrm{~mm} /$ day to $20 \mathrm{~mm} /$ day in increments of $1 \mathrm{~mm} /$ day) and minimum irrigation intervals ( 3 days to 15 days in increments of 1 day) to capture conditions from highly restricted up to effectively unrestricted irrigation system capacity. Results are used to illustrate the importance of accounting explicitly for impacts of limited intraseasonal irrigation capacity on seasonal crop-water production relationships, and, in particular, how production risks are affected by the way in which irrigation constraints are specified within crop growth simulations.

For each set of simulations described above, a common set of climate and irrigation management scenarios are used. 30 years (1987-2016) of historic 
speed, solar radiation) were obtained from an observation station in Amarillo, Texas (available from: https://www.ncdc.noaa.gov). Using these data the final weather input needed to run AquaCrop-OS, reference crop evapotranspiration, was estimated using the ASCE Standardized Penman-Monteith method (Walter et al. 2000). Irrigation was assumed to be triggered based on observed soil moisture status on each day of the growing season, consistent with reported practices in the region (U.S. Department of Agriculture, 2013). The soil moisture level at which irrigation was triggered is varied for each of the crops three main growth periods (early, middle, and late season), from $0 \%$ to $95 \%$ of total ${ }_{610}$ available water (i.e. water held in the soil between field capacity and permanent wilting point) in increments of $5 \%$ yielding a set of 8,000 unique possible irrigation strategies. Soil type in the model was assumed to be a Pullman clay loam, the most common soil type for maize production in the Texas High Plains region (Baumhardt et al., 1994). Crop growth parameters in AquaCrop-OS were set equal to values reported in a previous calibration of the model in the region by Heng et al. (2009), who demonstrated that AquaCrop is able to simulate accurately maize yield response to water. Finally, we assume that the crop is irrigated using a center-pivot system with application efficiency of $90 \%$, the soil water content is equal to $80 \%$ of total available water at planting in each year, and that the date of planting is May 1.

\section{Results and discussion}

\subsection{Crop-water production function}

Figure 3 illustrates the simulated relationship between total seasonal irrigation and crop yield, averaged across 30 historic climate years, for each of the 8000 irrigation management strategies considered in our example application. Consistent with the findings of previous studies based on crop coefficient modeling approaches (Scheierling et al., 1997, Smilovic et al., 2016), Figure 3 demonstrates that there is large variability in crop yield returns to seasonal irrigation depending on how irrigation is scheduled over the growing season.

${ }_{630}$ Figure 4 summarizes the magnitude of this variability in crop yields for different levels of seasonal irrigation, illustrating that variability exceeds 4 tonne/ha (greater than $30 \%$ of maximum expected crop yields of around 13.5 tonne/ha) for levels of expected total seasonal irrigation water use of between approximately $200 \mathrm{~mm}$ and $600 \mathrm{~mm}$ per year. This is due to the fact that, in this range, a wide range of irrigation management strategies have similar expected water uses, but very different expected crop yields as a result of when limited irrigation is scheduled within the growing season. In contrast, for very low (less than $200 \mathrm{~mm} / \mathrm{yr}$ ) or high (greater than $600 \mathrm{~mm} / \mathrm{yr}$ ) levels of expected water use, variability in expected crop yields is smaller as irrigation management strate${ }_{640}$ gies tend towards consistently under or fully irrigating the crop throughout the entire growing season, and, as a result, intraseasonal timing of irrigation has less significant impacts on final crop yields. These findings demonstrate that how farmers schedule irrigation within the growing season, which with few exceptions has been often ignored in agronomic and hydro-economic research, has 


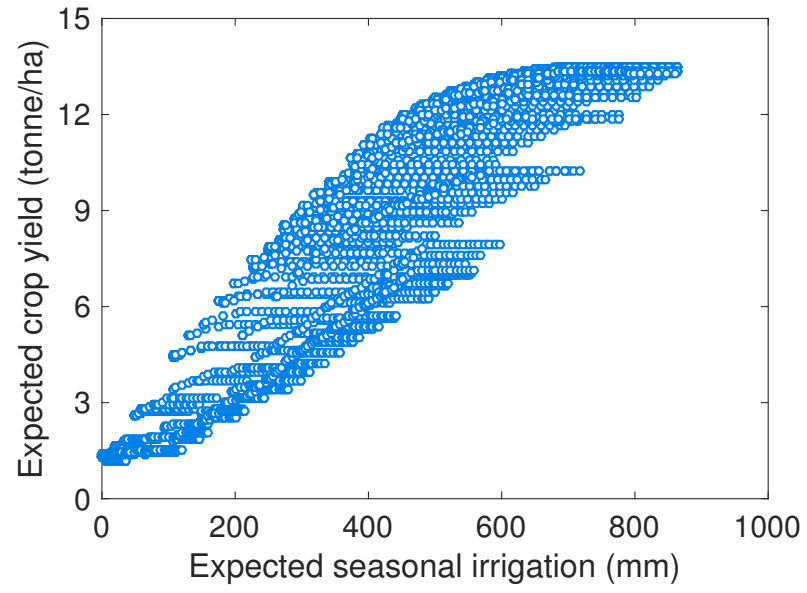

Figure 3: Simulated relationship between expected seasonal irrigation ( $\mathrm{mm}$ ) and expected crop yield (tonne/ha) for maize in Amarillo, Texas based on 30 years of historic weather data. Each dot represents a specific intraseasonal irrigation management strategy, specified based on the choice of soil moisture target strategy during the crop growing season

large impacts on crop yields at the end of the growing season. To adequately estimate crop-water production functions and the value of irrigation water for farmers, it is therefore critical to model explicitly the intraseasonal distribution of irrigation water use in a way that is consistent with actual irrigation management practices and intraseasonal water supply availability.

Using the data displayed in Figure 3 a crop-water production function is developed as described in Section 3.1 by extracting irrigation management strategies that maximize crop yields in each $25 \mathrm{~mm}$ total seasonal irrigation bin (e.g. $0-25 \mathrm{~mm}, 25-50 \mathrm{~mm}$, etc). The resulting fitted crop-water production function is shown in Figure 5, and exhibits a concave, curvilinear shape comparable to 655 that shown in Figure 1. Implicit to the crop-water production function shown in Figure 5 are two main assumptions: (i) that the production function relates expected, rather than actual, seasonal irrigation to crop yield, and (ii) that the farmer adopts the same intraseasonal irrigation management strategy each season in order to maximize expected crop yields. These assumptions capture realistically the reality that farmers make irrigation decisions based on rules/heuristics, and, due to uncertainty about future weather conditions, do not know precisely how much water will need to be applied over the season or how irrigation scheduling should be adjusted in any individual year to optimize water use. This is in contrast to existing approaches for developing crop-water ${ }_{665}$ production functions that overstate farmers' capacity to optimize intraseasonal irrigation scheduling (Brumbelow and Georgakakos, 2007; Schütze and Schmitz, 2010 García-Vila and Fereres, 2012 [Linker et al. 2016), or, alternatively, neglect impacts of stochastic climate conditions and non-linear crop growth dynamics on expected crop yield response to water inputs (Scheierling et al., 1997.

670 Smilovic et al. 2016). Significantly, our proposed simulation approach therefore 


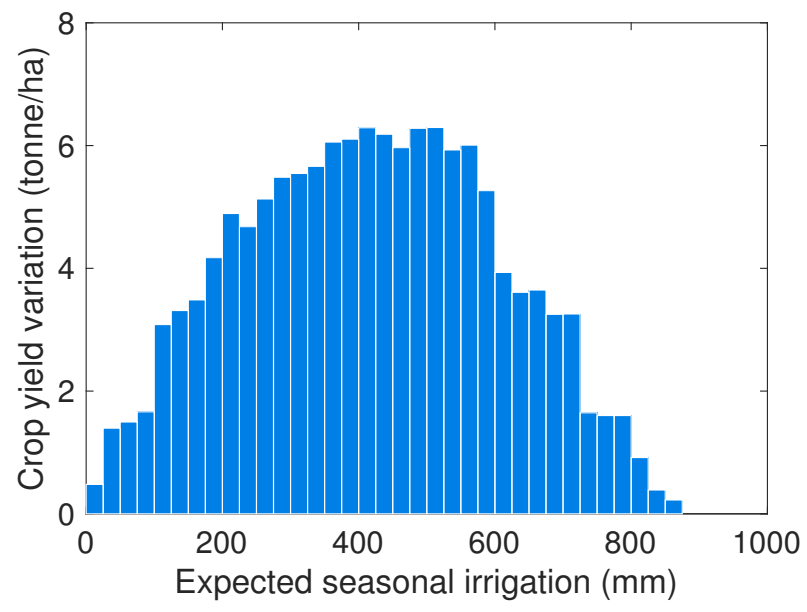

Figure 4: Variability in maize yields (tonne/ha) for different levels of expected seasonal irrigation water use due to the choice of intraseasonal irrigation scheduling rules

provides a robust method for estimating farmers' expectations of seasonal crop yield response to water conditional on realistic assumptions about irrigation decision rules and information availability, and, using these functions, for predicting the impacts of agricultural water policies on irrigation water demands and farm profits based on these production relationships.

From the crop-water production function shown in Figure 5 , it is possible to also relate back any given level of expected seasonal irrigation water use to a unique intraseasonal irrigation strategy. Several examples of extracted intraseasonal strategies are illustrated for points along the crop-water production function shown in Figure 5. These points demonstrate that, as expected seasonal irrigation is reduced in our example application, the farmer will choose to maintain higher soil moisture targets (and therefore allocate a greater proportion of expected total seasonal water use) in the early and middle stages of crop development, which are when water deficits have the greatest potential negative 685 impacts on maize yields (Doorenbos and Kassam, 1979; Steduto et al., 2012). Importantly, this illustrates how our simulated crop-water production functions can also provide additional information about how changes in seasonal water supply/availability may alter within-season distributions of irrigation water use. In particular, such information can be valuable for assessing how a change in water management policy, which typically are designed principally to reduce total seasonal water use, may alter timing of irrigation demand, and, in turn, potentially create unintended impacts on freshwater ecosystems or other water users within a catchment who may be highly sensitive to timing of irrigation abstractions within a season or year. Critically, such information also could ${ }_{695}$ not be obtained from existing simulation modeling approaches used to estimate crop-water production functions for economic water policy analysis, which do not acknowledge explicitly intraseasonal scheduling decisions or how these are 


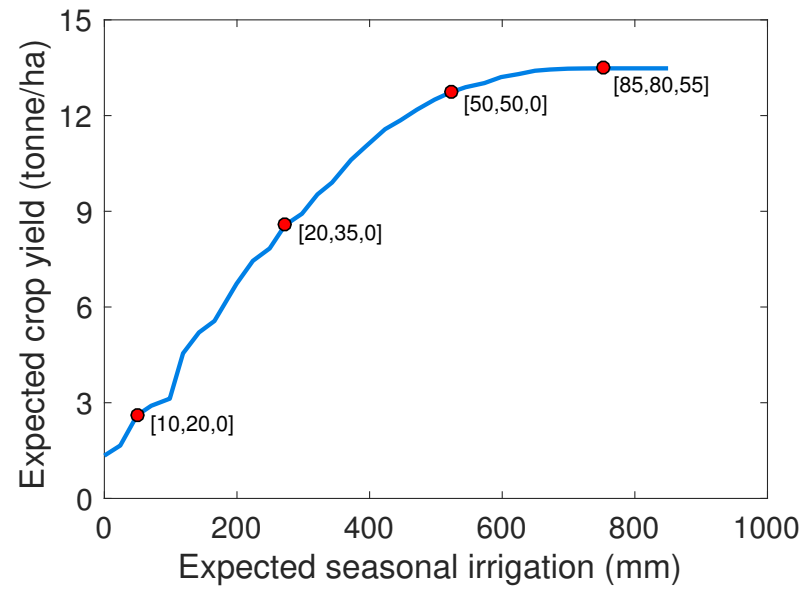

Figure 5: Crop-water production function showing the relationship between expected total seasonal irrigation $(\mathrm{mm})$ and expected crop yield (tonne/ha) extracted from the simulated points shown in Figure 3 Circles and associated annotations illustrate examples of how each level of expected total seasonal irrigation maps to a unique intraseasonal irrigation strategy, in this case a vector of three values representing the soil moisture levels (\% of total available water) at which irrigation is triggered in the early, middle, and late stages of crop development

affected by changes in the seasonal availability or allocation of water to agriculture as a result of policy or climatic changes.

It is important to note that in this example application we have assumed that farmers are able to adjust freely total irrigation water use between individual growing seasons (although scheduling rules do not change as noted above). This is a realistic representation of many major irrigation systems worldwide, in particular those supplied by groundwater, where extraction is often unregulated 705 pr restricted based on average water use over multi-year periods (Palazzo and Brozović, 2014, OECD, 2015). However, in some circumstances, for example when farmers are allocated a fixed and binding quantity of water each year as is more common in surface water irrigation systems, there may be less flexibility to adjust water use interannually. We do not explore this scenario explicitly in this paper. Nevertheless, such constraints could be incorporated easily within our proposed framework by introducing an additional constraint to limit further irrigation once a specified allocation limit is reached in any given simulation year. In this case, we hypothesize that expected crop yields are likely to be reduced relative to those shown in Figure 5, due to the additional production 715 risk created by the inflexibility of fixed annual abstraction limits. However, further research is required to test this hypothesis and evaluate the relative economic value of flexibility in abstraction management rules in the context of climatic variability and uncertainty faced by farmers. 


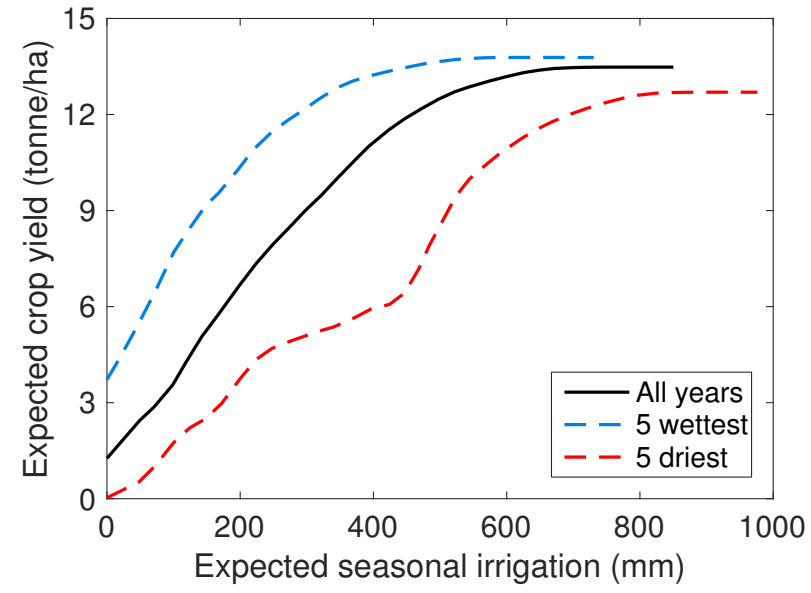

Figure 6: Crop-water production function showing the relationship between expected total seasonal irrigation $(\mathrm{mm})$ and expected crop yield (tonne/ha), where expected yields and irrigation water are determined considering: (i) all 30 years of historic climate data, (ii) five wettest years $(1988,1989,1996,2008$, and 2015) in the historic time series, or (iii) five driest years $(1990,1998,2000,2011$, and 2012) in the historic time series

\subsection{Effects of climate expectations} assumption that the farmer considers all 30 years of historic weather data when evaluating expected irrigation water requirements and crop yields for each potential irrigation management strategy. However, alternative assumptions could also be made about farmers' beliefs about future climate. For example, farmers son is likely to be wetter or drier than average (e.g. from seasonal forecasts Shafiee-Jood et al. (2014); Lorite et al. (2015)), or may base expectations on a smaller subset of more recent years of observed climate conditions (Ding et al. 2009 ). In this context, it may be more realistic to generate crop-water produc730 tion functions based on a subset of historic years, which more accurately reflects farmers' expectations of irrigation water requirements when making decisions about land allocation and intraseasonal scheduling decisions.

To demonstrate the capacity of our proposed simulation framework to capture the effects of different climate expectations on the crop-water production function, we have repeated the analysis described in Section 3.1 to generate two additional crop-water production functions where expectations about irrigation water demands and crop yields for each of the 8000 potential irrigation management strategies are based on: (i) 5 driest years (1990, 1998, 2000, 2011, and 2012), and (ii) 5 wettest years $(1988,1989,1996,2008$, and 2015) in the his-

740 toric climate time series. Figure 6 shows a comparison of these two crop-water production functions with the functional relationship generated previously in Section 4.1 based on the full 30-year historic climate record.

From Figure 6 it is clear that farmers' expectations about possible climate 
variability have large impacts on the resulting functional relationship between crop yield and total seasonal irrigation. Unsurprisingly, results show that if the farmer expects climate to be drier than average, the amount of irrigation that is expected to be required to achieve a given level of crop yield is greater than if climate conditions are expected to be wetter than average. However, the magnitude of this difference is particularly striking, illustrating the degree 750 of inter-annual climate variability observed in the Texas High Plains region. For example, expected irrigation water use to achieve an expected crop yield of 12 tonne/ha is equal to $284 \mathrm{~mm}$ when the crop-water production function is based on expectations of wetter climate conditions during the growing season, compared to $457 \mathrm{~mm}$ when considering the full range of historic conditions and $694 \mathrm{~mm}$ when drier climatic years are anticipated. This result is consistent with previous studies of irrigation water use in the High Plains region and United States more broadly (Russo and Lall (2017)), which demonstrate large variability in inter-annual in irrigation water use that is expected to be exacerbated in the future due to increasing extreme weather events caused by climate change.

Figure 6 also demonstrates that, depending on beliefs about future climate, the crop-water production function also may not exhibit the typical curvilinear shape (i.e. Figure 1) that has been assumed in previous studies of deficit irrigation practices (Barrett and Skogerboe, 1980; English, 1990, English et al. 2002, Fereres and Soriano, 2007 Geerts and Raes, 2009). In particular, when

765 climate is expected to be drier than average, the crop-water production function is shown to become increasingly non-monotonic, in particular for lower levels of expected seasonal irrigation water use. This effect is due to the fact that, in drought years in particular, a minimum amount of irrigation water may often need to be applied to avoid early crop die-off or to ensure that the crop develops fully to maximize potential yield returns from irrigation. Consequently, in drought years, assuming a standard curvilinear crop-water production relationship may lead to a mis-specification of the farmers' water use decision-making, and, critically, to an underestimation of the likely economic impacts of water supply restrictions or allocation decisions on farmer profits and livelihoods.

\subsection{Impacts of water availability constraints}

The analyses described so far have assumed that the farmer faces no physical or regulatory constraints that would limit or restrict intraseasonal irrigation decision-making. However, in many regions, farmers face constraints to when and how they can apply irrigation during the growing season, which may lead to 780 greater risk of water stress and crop yield reductions (Scheierling et al., 1997) in particular during drought years (Foster et al., 2014). In the Texas High Plains region, for example, many farmers have experienced declining well yields over recent years that limit the volume of groundwater that can be abstracted for irrigation on any given day of the growing season (Colaizzi et al., 2009, Foster et al., 2014, Haacker et al., 2015). Resulting constraints to intraseasonal irrigation decisions can be represented in terms of a restriction on either: (i) maximum depth of irrigation per day, or (ii) minimum number of days between 
irrigation events. For each of these two potential specifications of well yield constraints, Figure 7 shows the resulting crop-water production functions simulated using the framework outlined in Section 3.1 .

From examination of Figure 7, it is clear, irrespective of how constraints are imposed, that limited irrigation pumping capacity has a significant impact on seasonal crop yield response to irrigation water inputs. Two key effects are observed as either the maximum daily irrigation rate is decreased (Figure $7 \mathrm{a}$ ) or 795 the minimum interval between irrigation events is increased (Figure 7b). First, the crop-water production function is shifted to the left (inwards) as application constraints increasingly restrict the total seasonal depth of irrigation that can be applied over the growing season. Additionally, the crop-water production function also shifts downwards due to the fact that irrigation constraints limit 300 farmers ability to maintain desired soil moisture levels, resulting in reductions in expected crop yield returns to seasonal irrigation relative to if intraseasonal irrigation decisions had been unconstrained. These effects could not have been predicted without considering explicitly the constraints imposed by low well yields on farmers' ability to use irrigation to buffer crop production against water ${ }_{05}$ deficits during the growing season. Significantly, these factors typically are not considered in assessments of the impacts of aquifer depletion on agricultural productivity and resilience to drought (e.g. Cotterman et al. (2018)), which therefore are likely to lead to underestimate the potential value of policies to conserve groundwater resources as a buffer against future climate variability and change.

Additionally, the results presented in Figure 7 also provide insights about the likely impacts of well yield reductions on agricultural production and resilience to climate variability in regions that are experiencing severe long-term aquifer depletion, such as the Texas High Plains. In the Texas High Plains, the dominant method of irrigation are center-pivot systems that typically irrigate a circular area of around 52.65 ha (130 acres). Taking this irrigated area as fixed, it is possible to convert the daily application constraints and minimum irrigation intervals plotted in Figure 7 to equivalent groundwater well yields by noting that well yield is equal to maximum daily irrigation depth multiplied by 820 the irrigated area, divided by the minimum interval between irrigation events. Plotting the relationship between well yield and maximum expected crop yield for each simulated irrigation constraint (Figure 8), it is shown that the method used to define well yield constraints has a noticeable impact on the sensitivity of crop yields to reductions in groundwater well yields. In particular, crop yields are more sensitive to reductions in well yields when well yield constraints are imposed as limits on the maximum daily depth of irrigation. Previous research has largely modeled biophysical and economic impacts of declining well yields using production functions that vary according to changes in the maximum daily depth of irrigation (Lamm et al., 2007, Foster et al., 2014, 2015, Kisekka et al.,

830 2017). However, the results shown in Figure 8 suggest that economic outcomes may differ if constraints, and their resulting impacts on crop-water production relationships, instead affect farmers' irrigation decision-making through changes in the minimum interval between irrigation events. Specifically, Figure 8 sug- 
(a)

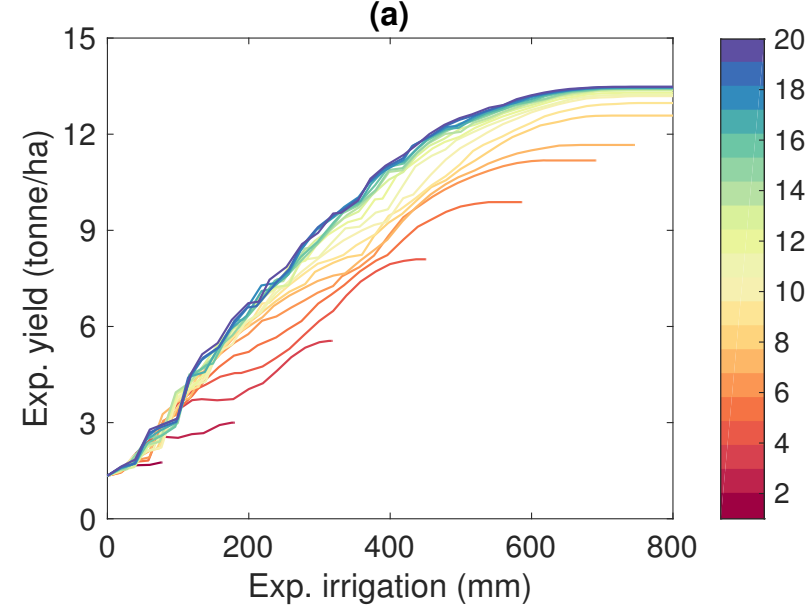

(b)

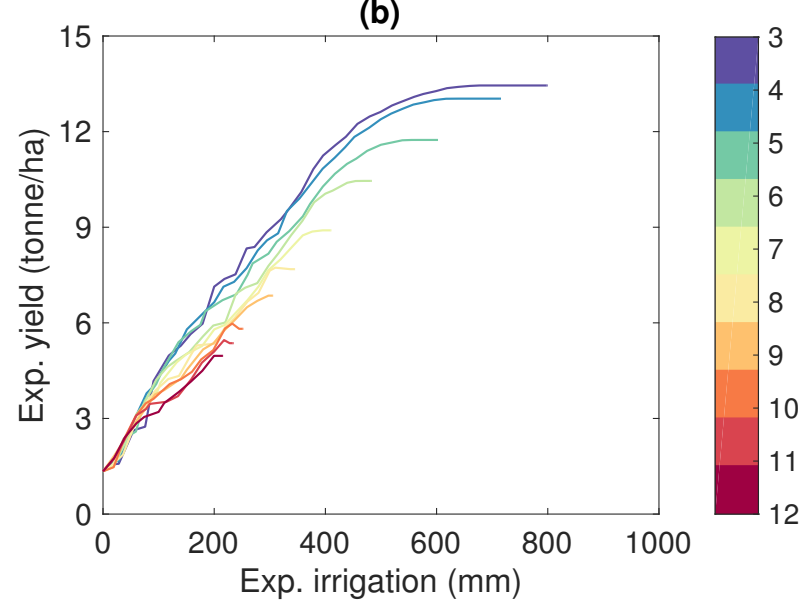

Figure 7: Simulated relationship between expected total seasonal irrigation and crop yield based on 30 years of historic climate data, considering constraints to intraseasonal irrigation decisions imposed on: (a) the maximum daily depth of irrigation water that can be applied $(\mathrm{mm})$, and (b) the minimum interval between irrigation events (days) 


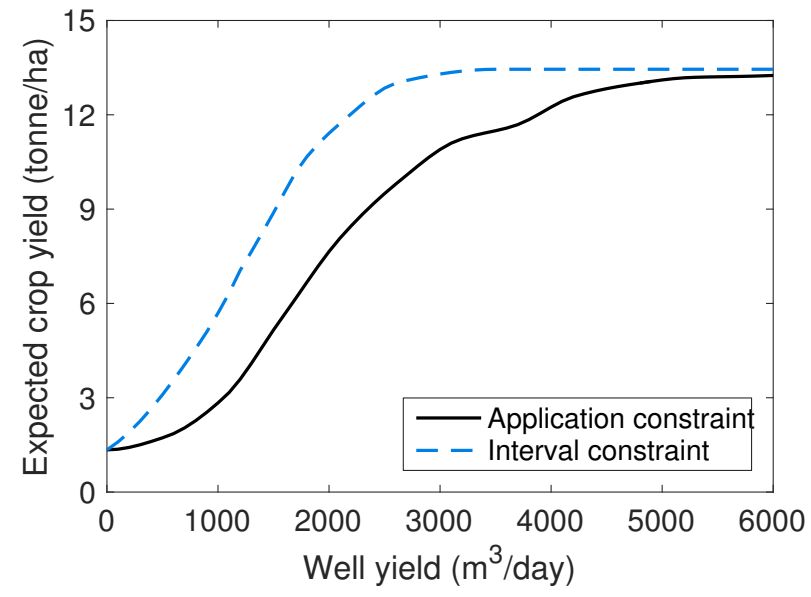

Figure 8: Simulated relationship between well yield $\left(\mathrm{m}^{3} /\right.$ day $)$ and maximum expected crop yield (tonne/ha) based on 30 years of historic weather data, assuming a typical centre-pivot system irrigating a circular area of 52.6 ha. Two lines are plotted, where well yield constraints are imposed via limits on: (i) the maximum daily depth of irrigation ( $\mathrm{mm}$ ), or (ii) the minimum interval between irrigation events (days)

gests that farmers may be able to maintain irrigated production with lower well yields than previously appreciated by adjusting the interval between irrigation events rather than the maximum depth of irrigation. However, further research is required to determine the persistence of this effect beyond the single case study examined in this paper, and the extent to which each of these modeling approaches reflect actual irrigation practices adopted by farmers in the Texas High Plains and other major groundwater irrigation systems.

\subsection{Applications and limitations}

Our proposed framework for simulating crop-water production functions provides more realistic estimates of crop yield response to water in regions where farmers face significant: (i) uncertainty about expected irrigation water requirements and crop yields, and/or (ii) constraints to intraseasonal scheduling of irrigation applications. These conditions are typical of a large proportion of agricultural regions worldwide. For example, in many locations not just including the High Plains, irrigation is used to supplement rainfall and buffer production against weather variability during the crop growth season. Farmers decisions about water use and allocation thus are strongly conditioned on weather expectations, in particular when making pre-season extensive margin choices about irrigated area and crop selection before actual weather is observed. Furthermore, while our analysis focuses on one specific example of a constraint to irrigation scheduling imposed by limited well yields, other comparable restric855 tions to farmers' irrigation decision-making also occur in both surface water and groundwater systems. In groundwater-fed systems, water supply reliability may be affected by interruptions to energy supply for pumping caused by contracted 
(Mieno, 2014) or unplanned (Shah et al., 2008) power outages, along with limits to well access in smallholder systems where pumping infrastructure often is communally owned. Similarly, in surface water systems, availability of water may not be matched fully to crop water needs where some farmers have lower priority water rights or depend directly on uncertain or poorly timed canal deliveries and operations (O'Keeffe et al., 2016; Christian et al.). Each of these factors may lead to sub-optimal scheduling, which, depending on the severity of 865 the constraint, are likely to lead to reductions in crop yields such as observed in Figure 7 .

Crop-water production functions generated using our proposed simulation approach have several potential applications within hydro-economic assessments of agricultural production and water management. Specifically, economists and water managers may use these production functions to develop improved estimates of how the total and marginal economic value of irrigation water will vary over space and time in agricultural regions due to differences in biophysical conditions, irrigation technologies and management practices, and constraints to irrigation decision-making. Using this information, more reliable predictions 875 can be made about the expected distributional impacts of future changes in water availability, for example due to shifts in climate conditions or the introduction of new water policies or supply infrastructure, on agricultural production, farm profitability, and rural economies more broadly. Improved understanding of the value of irrigation water in agriculture based on our simulated produc${ }_{880}$ tion functions can also provide valuable information about the likely costs of policies designed to incentivize re-allocation of water away from agriculture to other sectors (e.g. water markets or transfers), for example to urban users or to meet ecological demands of the environment and freshwater ecosystems. Finally, for common-pool water resources such as groundwater, simulated production functions may also aid economic decision-making about optimal inter-temporal groundwater extraction rates, in particular by accounting for impacts of future resource depletion on seasonal and intraseasonal water supply reliability as a result of declining well yields.

Nevertheless, it is important to note that there will be situations in which the additional modeling and data requirements required by our framework may not be fully justified in the context of economic analysis of agricultural water use and policy. Where irrigation is the sole source of water for agriculture and farmers face no-binding restrictions to irrigation scheduling, it is likely that the range of climate and irrigation management scenarios simulated could be reduced significantly to minimize the computational burden of our approach without compromising the accuracy of simulated production functions. Similarly, in regions that have diverse cropping patterns, in particular mixes of both annual and perennial crops, use of a process-based crop models may be more challenging than for the case study application presented here. In these circumstances,

900 simpler crop coefficient models (e.g. Allen et al. (1998)) may be preferred to estimate yield response to water due to their lower input requirements, at the expense of more detailed representation of crop responses to water stress. An example would be surface water irrigated agricultural regions in parts of the 
western United States, where rainfall is negligible during the summer growing season and farmers face fewer constraints to intraseasonal irrigation scheduling due to regulation of flow releases by multiple, interconnected surface reservoirs. Despite this, our proposed methodology may still have value in these systems in some years or locations. For example, many river basins are predicted to experience increased volatility in rates and timing of snowmelt as a result of 910 climate change, which may lead to curtailment of surface water deliveries to junior water rights holders at critical periods of crop development (Vano et al. 2010, Yoder et al., 2017). Additionally, in drought years, many farmers also rely on groundwater to buffer production against partial surface water deliveries resulting from low reservoir levels. In these situations, physical groundwater 915 pumping constraints (i.e. low well yields) may have large impacts on crop yields, and modeling such constraints would therefore be important to predict accurately economic losses experienced by producers (Foster et al., 2017c).

In the agricultural sector there has also been increasing emphasis in recent years on the development of precision irrigation technologies, such as variable rate irrigation systems or soil moisture monitoring, to enable farmers to optimize use of limited irrigation water (Evans and Sadler, 2008; Lichtenberg et al., 2015). By reducing non-consumptive water losses, precision irrigation technologies may help farmers to overcome partially constraints to intraseasonal irrigation decision-making, thus reducing differences between our proposed sim925 ulation framework and existing methods for estimating crop-water production functions. Impacts of precision agricultural technologies could be analyzed using our proposed framework by altering the assumed efficiency of irrigation applications, thus allowing comparison between production functions and resultant farm economic outcomes with and without adoption of precision irrigation technologies. Nevertheless, it is also important to recognize that in many cases precision irrigation technologies are unlikely to enable farmers to overcome irrigation constraints fully, for example where well yields are chronically reduced due to long-term aquifer depletion (Foster et al., 2014). In these situations, explicit modeling of the effects irrigation constraints on crop-water production 935 functions will remain essential for understanding the value of irrigation as a buffer against weather variability and for assessing benefits of policies to minimize future increases in water scarcity for agriculture.

Finally, in this study, we focus principally on the simulation of crop-water production functions in terms of the relationship between seasonal irrigation 94 water applications and crop yields. However, in some regions, policymakers and water managers are also increasingly interested in how changes in irrigation management practices or climate conditions will impact consumptive water use (i.e. crop evapotranspiration) and resulting basin-scale water budgets (Ward and Pulido-Velazquez, 2008). Process-based crop growth models, such as used 945 in this study, simulate explicitly crop consumptive water use and the proportion of applied irrigation that is lost to return flows during the growing season Foster et al. (2017a). Future research therefore should seek to extend our proposed framework to evaluate how farmers' intraseasonal irrigation scheduling decisions affect not only crop yields, but also the balance between applied and 

pacts on inter-sectoral water allocation at basin scales. Such an extension would be especially relevant in the context of previously noted trends in adoption of precision irrigation technologies, which may enable farmers to reduce seasonal application rates but have much smaller impacts on rates of consumptive water 955 use and, therefore, the availability of water for other users (Pfeiffer and Lin, 2014 Fishman et al. 2015).

\section{Summary and conclusions}

Crop-water production functions define the relationship between seasonal irrigation water use and crop yield, and provide a key input to economic studies of agricultural water use and inter-sectoral water policy analysis. In this paper, we develop a new methodology for simulating crop-water production functions using process-based crop growth models. Our proposed approach extends existing methods for simulating crop-water production function, specifically by accounting for interacting effects of both: (i) uncertainty in farmers' expectaconditions, and (ii) yield reductions resulting from physical and regulatory constraints to farmers' intraseasonal irrigation decision-making. While the latter have been considered as part of previous simulation efforts (Scheierling et al. 1997: Shani et al., 2004: Smilovic et al., 2016), our approach is the first to evalu-

970 ate joint impacts of intraseasonal irrigation constraints and weather uncertainty on crop-water production functions using process-based crop growth models.

To illustrate the utility of our new simulation framework, we generate several crop-water production functions under alternative assumptions about the information structure and constraints underlying farmers' irrigation decision-making for an example application of irrigated corn production in the Texas High Plains region of the United States. Simulated crop-water production function demonstrate that seasonal irrigation water use alone is a weak predictor of expected crop yields, and that, additionally, it is necessary to consider the interaction between the temporal distribution of water use within the growing season, un-

980 certain stochastic climate conditions, and physical or regulatory constraints to irrigation water supply during the crop growth season. Our findings show that constraints to the rates and timing of irrigation caused by limited well yields, in particular, significantly alter predictions of seasonal crop yield response to water for groundwater-fed irrigation systems in our case study of the Texas High of intraseasonal constraints are affected by how restrictions are imposed within model simulations, with expected crop yields observed to be less sensitive when minimum irrigation intervals rather than maximum daily irrigation depths are limited. This finding has broader implications beyond the main focus of this pa-

990 per, and, specifically, suggests that there is a need for improved understanding about farmers' adaptive responses to declining well yields in order to quantify reliably the economic impacts of aquifer depletion in the Texas High Plains and other regions. 
In conclusion, in this paper we develop a new methodology for simulat-

Barrett, J.H., Skogerboe, G.V., 1980. Crop production functions and the allocation and use of irrigation water. Agricultural Water Management 3, 53-64. doi:10.1016/0378-3774(80)90015-3.

Baumhardt, R., Lascano, R., Kreig, D., 1994. The physical and hydraulic properties of a Pullman and Amarillo soil on the Texas South Plains. Texas Agricultural Experimental Station, College Station, Texas, United States.

Bekchanov, M., Ringler, C., Bhaduri, A., Jeuland, M., 2015. How would the Rogun Dam affect water and energy scarcity in Central Asia? Water International 40, 856-876.

Bras, R.L., Cordova, J.R., 1981. Intraseasonal water allocation in deficit irrigation. Water Resources Research 17, 866-874. doi 10.1029/WR017i004p00866 
Brown, P.D., Cochrane, T.A., Krom, T.D., 2010. Optimal on-farm irrigation scheduling with a seasonal water limit using simulated annealing. Agricultural Water Management 97, 892-900. doi $10.1016 / \mathrm{j}$.agwat.2010.01.020

Brumbelow, K., Georgakakos, A., 2007. Determining crop-water production functions using yield-irrigation gradient algorithms. Agricultural Water Management 87, 151-161. doi:10.1016/j.agwat.2006.06.016

Cai, X., 2008. Implementation of holistic water resources-economic optimization models for river basin management - reflective experiences. Environmental Modelling \& Software 23, 2-18. doi $10.1016 /$ j.envsoft.2007.03.005.

Cai, X., McKinney, D.C., Lasdon, L.S., 2003. Integrated hydrologic-agronomiceconomic model for river basin management. Journal of Water Resources Planning and Management 129, 4-17.

Christian, P., Knodylis, F., Mueller, V., Zwager, A., Siegfried, T., . Water When It Counts : Reducing Scarcity through Irrigation Monitoring in Central Mozambique. World Bank, Washington, D.C., United States.

Colaizzi, P., Gowda, P.H .and Marek, T., Porter, D., 2009. Irrigation in the Texas High Plains: A brief history and potential reductions in demand. Irrigation and Drainage 58, 257-274. doi:10.1002/ird.418.

Cotterman, K.A., Kendall, A.D., Basso, B., Hyndman, D.W., 2018. Groundwater depletion and climate change: future prospects of crop production in the Central High Plains Aquifer. Climatic Change 146, 187-200.

Dinar, A., Knapp, K.C., Rhoades, J.D., 1986. Production function for cotton with dated irrigation quantities and qualities. Water Resources Research 22, 1519-1525. doi 10.1029/WR022i011p01519.

Dinar, A., Letey, J., 1996. Modeling economic management and policy issues of water in irrigated agriculture. Praeger, Westport, CT, USA.

Ding, Y., Schoengold, K., Tadesse, T., 2009. The impact of weather extremes on agricultural production methods: Does drought increase adoption of conservation tillage practices? Journal of Agricultural and Resource Economics $34,395-411$.

Doorenbos, J., Kassam, A.H., 1979. Yield response to water. FAO Irrigation and Drainage Paper No.33. Food and Agriculture Organization of the United Nations, Rome, Italy.

Elliott, J., Deryng, D., Müller, C., Frieler, K., Konzmann, M., Gerten, D., Glotter, M., Flörke, M., Wada, Y., Best, N., et al., 2014. Constraints and potentials of future irrigation water availability on agricultural production under climate change. Proceedings of the National Academy of Sciences 111, 3239-3244. doi $10.1073 /$ pnas.1222474110. 
English, M., 1990. Deficit irrigation. i: Analytical framework. Journal of Irrigation and Drainage Engineering 116, 399-412. doi 10.1061/(ASCE) 0733-9437(1990)116:3(399)

English, M.J., Solomon, K.H., Hoffman, G.J., 2002. A paradigm shift in irrigation management. Journal of Irrigation and Drainage Engineering 128, $267-277$.

Erfani, T., Binions, O., Harou, J., 2015. Protecting environmental flows through enhanced water licensing and water markets. Hydrology and Earth System Sciences 19, 675-689.

1080 Esteve, P., Varela-Ortega, C., Blanco-Gutiérrez, I., Downing, T.E., 2015. A hydro-economic model for the assessment of climate change impacts and adaptation in irrigated agriculture. Ecological Economics 120, 49-58. doi:10.1016/j.ecolecon.2015.09.017.

Evans, R.G., Sadler, E.J., 2008. Methods and technologies to improve efficiency of water use. Water Resources Research 44, W00E04.

FAO, 2011. The state of the world's land and water resources for food and agriculture. Managing systems at risk. Earthscan, Abingdon, UK.

Fereres, E., Soriano, M.A., 2007. Deficit irrigation for reducing agricultural n water use. Journal of Experimental Botany 58, 147-159. doi:10.1093/jxb/ erl165.

Fishman, R., Devineni, N., Raman, S., 2015. Can improved agricultural water use efficiency save Indias groundwater? Environmental Research Letters 10, 084022 .

Foster, T., Brozović, N., Butler, A., 2017a. Effects of initial aquifer conditions on economic benefits from groundwater conservation. Water Resources Research 53, 744-762. doi 10.1002/2016WR019365.

Foster, T., Brozović, N., Butler, A., Neale, C., Raes, D., Steduto, P., Fereres, E., Hsiao, T., 2017b. AquaCrop-OS: An open source version of FAO's crop water

n productivity model. Agricultural Water Management 181, 18-22. doi 10 . 1016/j.agwat.2016.11.015.

Foster, T., Brozović, N., Butler, A.P., 2014. Modeling irrigation behavior in 口 groundwater systems. Water Resources Research 50, 6370-6389. doi 10 . 1002/2014WR015620.

Foster, T., Brozović, N., Butler, A.P., 2015. Why well yield matters for managing agricultural drought risk. Weather and Climate Extremes 10, 11-19. doi: $10.1016 / \mathrm{j}$. wace.2015.07.003.

Foster, T., Brozović, N., Speir, C., 2017c. The buffer value of groundwater when well yield is limited. Journal of Hydrology 547, 638-649. 
García-Vila, M., Fereres, E., 2012. Combining the simulation crop model AquaCrop with an economic model for the optimization of irrigation man-

a agement at farm level. European Journal of Agronomy 36, 21-31. doi 10 . 1016/j.eja.2011.08.003

García-Vila, M., Fereres, E., Mateos, L., Orgaz, F., Steduto, P., 2009. Deficit irrigation optimization of cotton with AquaCrop. Agronomy journal 101, 477-487. doi:10.2134/agronj2008.0179s

Geerts, S., Raes, D., 2009. Deficit irrigation as an on-farm strategy to maximize crop water productivity in dry areas. Agricultural Water Management 96, $1275-1284$. doi $10.1016 / \mathrm{j}$.agwat.2009.04.009

Giuliani, M., Li, Y., Castelletti, A., Gandolfi, C., 2016. A coupled humannatural systems analysis of irrigated agriculture under changing climate. Water Resources Research 52, 6928-6947. doi 10.1002/2016WR019363

Haacker, E.M., Kendall, A.D., Hyndman, D.W., 2015. Water level declines in the High Plains Aquifer: Predevelopment to resource senescence. Groundwater 54, 231-242. doi $10.1111 /$ gwat.12350.

Hanks, R., 1974. Model for predicting plant yield as influenced by water use. Agronomy Journal 66, 660-665.

Heng, L.K., Hsiao, T., Evett, S., Howell, T., Steduto, P., 2009. Validating the FAO AquaCrop model for irrigated and water deficient field maize. Agronomy Journal 101, 488-498. doi 10.2134/agronj2008.0029xs.

Hexem, R.W., Heady, E.O., 1978. Water Production Functions for Irrigated Agriculture. Iowa State University Press, Ames, Iowa, United States.

Hoogenboom, G., Jones, J., Wilkens, P., Porter, C., Batchelor, W., Hunt, L., Boote, K., Singh, U., Uryasev, O., Bowen, W., et al., 2004. Decision support system for agrotechnology transfer (DSSAT): Version 4.0. University of Hawaii, Honolulu, Hawaii, United States.

Igbadun, H.E., Ramalan, A., Oiganji, E., 2012. Effects of regulated deficit irrigation and mulch on yield, water use and crop water productivity of onion

n in Samaru, Nigeria. Agricultural Water Management 109, 162-169. doi 10. 1016/j.agwat.2012.03.006.

Igbadun, H.E., Tarimo, A.K.P.R., Salim, B.A., Mahoo, H.F., 2007. Evaluation of selected crop water production functions for an irrigated maize crop. Agricultural Water Management 94, 1-10. doi:10.1016/j.agwat.2007.07.006

Jensen, M., 1968. Water consumption by agricultural plants, in: Kozlowski, T. (Ed.), Water Deficits in Plant Growth. Academic Press, New York, USA, pp. $1-22$. 
Jones, J.W., Hansen, J.W., Royce, F.S., Messina, C.D., 2000. Potential benefits of climate forecasting to agriculture. Agriculture, ecosystems \& environment 82, 169-184. doi 10.1016/S0167-8809(00)00225-5

Kaboosi, K., Kaveh, F., 2012. Sensitivity analysis of FAO 33 crop wa-

ter production function. Irrigation Science 30, 89-100. doi 10.1007/ s00271-011-0263-7.

Kahil, M.T., Connor, J.D., Albiac, J., 2015. Efficient water management policies for irrigation adaptation to climate change in southern europe. Ecological Economics 120, 226-233. doi $10.1016 / \mathrm{j}$.ecolecon.2015.11.004.

1155 Keating, B.A., Carberry, P.S., Hammer, G.L., Probert, M.E., Robertson, M.J., Holzworth, D., Huth, N.I., Hargreaves, J.N., Meinke, H., Hochman, Z., et al., 2003. An overview of APSIM, a model designed for farming sys-

q tems simulation. European Journal of Agronomy 18, 267-288. doi 10.1016/ S1161-0301(02)00108-9.

1160 Kim, D., Kaluarachchi, J.J., 2016. A risk-based hydro-economic analysis for land and water management in water deficit and salinity affected farming regions.

n Agricultural Water Management 166, 111-122. doi:10.1016/j.agwat.2015. 12.019 .

Kipkorir, E., Raes, D., Massawe, B., 2002. Seasonal water production functions and yield response factors for maize and onion in Perkerra, Kenya.

n Agricultural Water Management 56, 229-240. doi 10.1016/S0378-3774(02) 00034-3

Kisekka, I., Schlegel, A., Ma, L., Gowda, P., Prasad, P., 2017. Optimizing preplant irrigation for maize under limited water in the High Plains. Agricultural Water Management 187, 154-163. doi $10.1016 / j$.agwat.2017.03.023.

Kuwayama, Y., Brozović, N., 2013. The regulation of a spatially heterogeneous externality: Tradable groundwater permits to protect streams. Journal of Environmental Economics and Management 66, 364-382.

Lamm, F., Stone, L., O'Brien, D., 2007. Crop production and economics in 1175 Northwest Kansas as related to irrigation capacity. Applied Engineering in Agriculture 23, 737-746. doi $10.13031 / 2013.24057$.

Lichtenberg, E., Majsztrik, J., Saavoss, M., 2015. Grower demand for sensorcontrolled irrigation. Water Resources Research 51, 341-358.

Linker, R., Ioslovich, I., Sylaios, G., Plauborg, F., Battilani, A., 2016. Optimal model-based deficit irrigation scheduling using AquaCrop: A simulation study with cotton, potato and tomato. Agricultural Water Management 163, 236243. doi $10.1016 / \mathrm{j}$.agwat.2015.09.011 
Loch, A., Wheeler, S., Bjornlund, H., Beecham, S., Edwards, J., Zuo, A., Shanahan, M., 2013. The role of water markets in climate change adaptation. National Climate Change Adaptation Research Facility, Gold Coast, Australia.

Lorite, I., Ramírez-Cuesta, J., Cruz-Blanco, M., Santos, C., 2015. Using weather forecast data for irrigation scheduling under semi-arid conditions. Irrigation Science 33, 411-427. doi 10.1007/s00271-015-0478-0.

Maneta, M., Torres, M.d.O., Wallender, W., Vosti, S., Howitt, R., Rodrigues, L., Bassoi, L., Panday, S., 2009. A spatially distributed hydroeconomic model to assess the effects of drought on land use, farm profits, and agricultural employment. Water Resources Research 45, W11412.

McKinney, D.C., Cai, X., Rosegrant, M.W., Ringler, C., Scott, C.A., 1999. Modeling water resources management at the basin level. SWIM Paper 6 . International Water Management Institute, Colombo, Sri Lanka.

McLaughlin, D., Kinzelbach, W., 2015. Food security and sustainable req source management. Water Resources Research 51, 4966-4985. doi 10.1002/ 2015WR017053.

Mieno, T., 2014. Essays in water resource economics. Ph.D. thesis. University of Illinois at Urbana-Champaign.

Minhas, B., Parikh, K., Srinivasan, T., 1974. Toward the structure of a production function for wheat yields with dated inputs of irrigation water. Water Resources Research 10, 383-393.

Monteith, J.L., 1996. The quest for balance in crop modeling. Agronomy Journal $88,695-697$.

Moore, M.R., Negri, D.H., 1992. A multicrop production model of irrigated agriculture, applied to water allocation policy of the bureau of reclamation. Journal of Agricultural and Resource Economics 17, 29-43.

Noël, P.H., Cai, X., 2017. On the role of individuals in models of coupled human and natural systems: Lessons from a case study in the republican river basin. Environmental Modelling \& Software 92, 1-16. doi:10.1016/j. envsoft.2017.02.010.

OECD, 2015. Drying Wells, Rising Stakes. Towards Sustainable Agricultural Groundwater Use. OECD, Paris, France.

1215 O'Keeffe, J., Buytaert, W., Mijic, A., Brozović, N., Sinha, R., 2016. The use of semi-structured interviews for the characterisation of farmer irrigation practices. Hydrology and Earth System Sciences 20, 1911-1924. doi:10.5194/hess-20-1911-2016.

Palazzo, A., Brozović, N., 2014. The role of groundwater trading in spatial water 1220 a management. Agricultural Water Management 145, 40-50. doi:10.1016/j. agwat.2014.03.004. 
Pfeiffer, L., Lin, C.Y.C., 2014. Does efficient irrigation technology lead to reduced groundwater extraction? Empirical evidence. Journal of Environmental Economics and Management 67, 189-208.

1225 Raes, D., Geerts, S., Kipkorir, E., Wellens, J., Sahli, A., 2006. Simulation of yield decline as a result of water stress with a robust soil water balance model.

口 Agricultural Water Management 81, 335-357. doi 10.1016/j.agwat. 2005. 04.006 .

Rao, N., Sarma, P., Chander, S., 1988. A simple dated water-production function for use in irrigated agriculture. Agricultural Water Management 13, 25-32. doi:10.1016/0378-3774(88)90130-8.

Russo, T.A., Lall, U., 2017. Depletion and response of deep groundwater to climate-induced pumping variability. Nature Geoscience 10, 105-108.

Scheierling, S.M., Cardon, G.E., Young, R.A., 1997. Impact of irrigation timing on simulated water-crop production functions. Irrigation Science 18, 23-31. doi $10.10072 \mathrm{Fs} 002710050041$.

Schütze, N., Schmitz, G.H., 2010. OCCASION: new planning tool for optimal climate change adaption strategies in irrigation. Journal of Irrigation and Drainage Engineering 136, 836-846. doi:10.1061/(ASCE) IR.1943-4774. 0000266

Semenov, M.A., Brooks, R.J., Barrow, E.M., Richardson, C.W., 1998. Comparison of the WGEN and LARS-WG stochastic weather generators for diverse climates. Climate Research 10, 95-107.

Shafiee-Jood, M., Cai, X., Chen, L., Liang, X.Z., Kumar, P., 2014. Assessing 1245 the value of seasonal climate forecast information through an end-to-end forecasting framework: Application to US 2012 drought in central Illinois. Water Resources Research 50,6592-6609. doi 10.1002/2014WR015822.

Shah, T., Bhatt, S., Shah, R., Talati, J., 2008. Groundwater governance through electricity supply management: Assessing an innovative intervention in Gu-

1250 jarat, western India. Agricultural Water Management 95, 1233-1242.

Shani, U., Tsur, Y., Zemel, A., 2004. Optimal dynamic irrigation schemes.

a Optimal Control Applications and Methods 25, 91-106. doi:10.1002/oca. 740.

Shani, U., Tsur, Y., Zemel, A., Zilberman, D., 2009. Irrigation production functions with water-capital substitution. Agricultural Economics 40, 55-66. doi:10.1111/j.1574-0862.2008.00359.x.

Smilovic, M., Gleeson, T., Adamowski, J., 2016. Crop kites: Determining cropwater production functions using crop coefficients and sensitivity indices. Ad-

口 vances in Water Resources 97, 193-204. doi 10.1016/j.advwatres.2016.09. 010 . 
Steduto, P., Hsiao, T.C., Fereres, E., 2007. On the conservative behavior of n biomass water productivity. Irrigation Science 25, 189-207. doi 10.1007/ s00271-007-0064-1.

Steduto, P., Hsiao, T.C., Raes, D., Fereres, E., 2009. AquaCrop - The FAO crop model to simulate yield response to water: I. concepts and underlying principles. Agronomy Journal 101, 426-437. doi 10.2134/agronj2008.0139s.

Steduto, P., Hsiao, T.C., Raes, D., Fereres, E., 2012. FAO Irrigation and Drainage Paper No.66: Crop yield response to water. Food and Agriculture Organization of the United Nations, Rome, Italy.

Stewart, J.I., Cuenca, R.H., Pruitt, W.O., Hagan, R.M., Tosso, J., 1977. Determination and utilisation of water production functions for principal California crops. W-67 Calif. Contrib. Proj. Rep. University of California, Davis, California, USA.

Stewart, J.I., Hagan, R.M., 1973. Functions to predict the effects of crop water deficits. Journal of the Irrigation and Drainage Division 99, 421-439.

Sunantara, B.J.D., Ramírez, J.A., 1997. Optimal stochastic multicrop seasonal and intraseasonal irrigation control. Journal of Water Resources Planning and Management 123, 39-48. doi:10.1061/(ASCE) 0733-9496(1997)123:1(39).

U.S. Department of Agriculture, 2013. Farm and Ranch Irrigation Survey 2013. United States Department of Agriculture, Washington, D.C., USA.

Vano, J.A., Scott, M.J., Voisin, N., Stöckle, C.O., Hamlet, A.F., Mickelson, K.E., Elsner, M.M., Lettenmaier, D.P., 2010. Climate change impacts on water management and irrigated agriculture in the Yakima River Basin, Washington, USA. Climatic Change 102, 287-317.

1285 Vaux, H.J., Pruitt, W.O., 1983. Crop-water production functions, in: Hillel, D. (Ed.), Advances in Irrigation 2. Academic Press, New York, USA, pp. $257-272$.

Walter, I.A., Allen, R.G., Elliott, R., Jensen, M., Itenfisu, D., Mecham, B., Howell, T., Snyder, R., Brown, P., Echings, S., et al., 2000. The ASCE standardized reference evapotranspiration equation. University of Idaho, Kimberley, Idaho, United States.

Ward, F.A., Pulido-Velazquez, M., 2008. Water conservation in irrigation can increase water use. Proceedings of the National Academy of Sciences 105, $18215-18220$.

1295 Yates, D., Sieber, J., Purkey, D., Huber-Lee, A., 2005. WEAP21 A demand-, priority-, and preference-driven water planning model: part 1: model characteristics. Water International 30, 487-500. doi:10.1080/02508060508691893 
Yoder, J., Adam, J., Brady, M., Cook, J., Katz, S., Johnston, S., Malek, K., McMillan, J., Yang, Q., 2017. Benefit-cost analysis of integrated water resource management: Accounting for interdependence in the Yakima Basin integrated plan. JAWRA Journal of the American Water Resources Association $53,456-477$.

Young, R., Loomis, J., 2014. Determining the economic value of water: concepts and methods. RFF Press, Washington, DC, United States.

1305 Zhang, H., Oweis, T., 1999. Water-yield relations and optimal irrigation scheduling of wheat in the Mediterranean region. Agricultural Water Management 38, 195-211. doi $10.1016 /$ S0378-3774(98) 00069-9. 